\title{
CREATIVITY IN FOREIGN LANGUAGE TEACHING
}

\author{
MONIKA ŠEVEČKOVÁ \\ Masaryk University, Language Centre

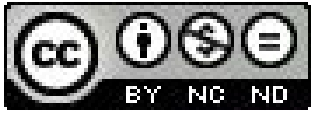 \\ Komenského nám. 2, 60200 Brno, Czech Republic \\ E-mail address: seveckova@email.cz
}

\begin{abstract}
Developing creativity in foreign language teaching provides students with the opportunity to effectively build language skills as well as increasing their motivation for learning. Practical examples are given using folklore materials (songs, tales, etc.) in learning Russian, as well as contemporary materials reflecting the culture of Russian speaking countries (films, poems, etc.). As well as increasing their ability in the target foreign language students also acquire factual information (realia) through creative language games. In this paper we describe recent findings in the field and propose possible directions for future research.

Key words: Cognitive linguistics, creativity, folklore, foreign language, game, motivation, pedagogy, Russian
\end{abstract}

\section{INTRODUCTION}

Who of us wouldn't want to live their life creatively and bring a little creativity into their everyday routine? Creativity is associated with interaction, fantasy, play, collaboration, change and experimentation or even with a positive approach, and is something every person needs. It is also relevant to classroom strategies and teaching styles and an integral part of pedagogy. The great challenge therefore, is the question of how to develop creativity in the teaching of foreign languages where our goal is to increase students' motivation for learning where it has been shown that a creative approach to studying leads to effective building of language skills.

Introducing elements of play into foreign language learning has been highly accentuated over recent years and has been used to provide variety in lessons in both elementary and secondary schools. Our contribution summarises our experience with using a creative approach in Russian as a foreign language seminars (levels B1 - B2) at the Faculty of Arts and Faculty of Economy of Masaryk University in Brno (Czech Republic). It reflects the search for a creative approach to teaching all the tested skills i.e. reading, writing, speaking and listening, and all combinations of these.

Introduction of creative methods into Russian language teaching is based on research of the author, as a survey during eight terms among circa 700 
students studying Russian language as a chosen optional foreign language for one or two terms at Masaryk University. The target of the research was to find out what is the motivation for the choice of studying the Russian language, what is increasing the motivation during the studies and what is stimulating their effort and knowledge, and whether the creativity is important for their studies.

\section{THEORETICAL FRAMEWORK}

Active learning means making use of processes in which the student, on the basis of his own activity, assimilates new information, learning through discovery, trial and error, making his own decision on what information to accept or reject and how to use it in the future (Kotrba, \& Lacina, 2011, p. 97). As part of this autonomy, emphasis is placed on critical thinking and arguing both the student's own stance and considering the opinions of other students in the group. It is of importance to encourage the creativity and inquisitiveness in order to develop the critical, therefore individual thinking, as well as choosing and analysing the relevant information.

There are a lot of definitions to be found in professional literature describing creativity. According to Ellis Paul Torrance there is emphasis on novelty and originality (Torrance, 1962), Josef Maňák is talking about creativity as a natural human quality (Maňák, 1998), Robert Sternberg says that „creativity is a habit" and "like any habit, creativity can either be encouraged or discouraged" (Sternberg, 2012), Alane Jordan Starko is pointing out the necessity of awakening the creativity in students in order to motivate, study and enjoy (Starko, 2014).

With the activation methods (games, discussions, situational methods, etc.) used the teacher should always take into consideration the type of student (visual, audial, kinaeshetic). It has been shown that combining various types of activity for individual types of students can be very effective (for visual types - supplementing listening with pictures, for audial types socalled running dictation in pairs for writing tasks, for students more inclined towards kinaesthetic types of learning - work on projects or creating posters) (Lojová, \& Vlčková, 2011, pp. 48-55). Used activation methods support divergent thinking, therefore developing creativity with emphasis on the fact, that there could be more than one solution.

Linguistic games and activation methods don't have to be used only in association with vocabulary and grammar learning (compare with "learning games"; Meier, 2000, p. 147). We are convinced that, besides just language skills students should also be equipped with a knowledge of the wider context of the language such as realia, in this case use of folklore materials (eg. songs, fairytales, sayings, tongue-twisters, jokes etc.) (Eibenová, Vavrečka, \& Eibenová, 2013, pp. 139-168). Use of these materials is based on findings in cognitive linguistics (work with texts) and an effort to support cognitive 
structures in human thinking. The correct excercise of cognitive functions helps to increase the efficiency of work with information and raise the attitude to study among students.

Knowledge of a foreign language, in our opinion, is also formed by linguistic cultural awareness - this concerns so-called "cultural key words" on whose basis the cognitive-conceptual system of a Slavic language, in this case Russian as a foreign language (for Czech students) can be explored. These "key words" occurring, for example, in folklore texts create a so-called "linguistic image" and reflectthe mentality of the given nation (Alefirenko, \& Korina, 2011, pp. 110-113). Through reconstruction of this "linguistic image" for an individual language we can interpret the reality hidden in the given foreign language, understand that language better and make it our own (Serebrennikov, Kubriakova, \& Postovalova, 1988).

This "linguistic image" can, in the case of using folklore material, in fairytales mean an abundance of animal motifs (eg. the fairytale "Лисица и заяц", "Ворона") and in songs themes such as the struggle for freedom (eg. songs from the Russian bards Vladimir Vysotsky or Bulat Okudzhava), in the phraseological motif fate and home (eg. "Ни в сказке сказать, ни пером описать"; "Кашу не сваришь"; "Когда рак на горе свистнет"; “Счастливые часов не наблюдают"; “Жить своим домом“; “Искать корни“), and in the case of anecdotes, the motif of the fight against prejudice. All these areas (songs, fairytales, phraseology, jokes) form for Russians one of the main pillars of communication, and even everyday conversation is often scattered with these proverbs, sayings, jokes and lines from songs. We therefore consider it important for students to know and actively use these devices to successfully communicate in this language.

It is appropriate to always include activational practice (so called warmup, for individual practise, for couples, groups, etc.) after introducing individual (grammatical) points, vocabulary, etc. These activities are a sure form of revision and reinforcement exercise.

\section{RESULTS}

Example no.1: Development of vocabulary through mime (level B1, length of activity 15-20 minutes)

Task (no.1) for students divided into groups of three:

Working in two groups for the sake of interaction, (ie. two groups of three students) with a specific, well-known fairytale (eg. "Промышку-норушку") (Сказки и рассказы для детей, 2010, p. 11-13), where one group has to mime the fairytale and the other group has to narrate (or dub) the story as they perform it. Halfway through the story the groups change roles. After wards they can discuss the experience and how it went.

In another seminar we can reinforce the students' grasp of the material covered by, for instance, using the following activity. We prepare the afore 
mentioned fairytale, but with some parts rubbed out so that there are 4-5 sentence beginnings in each individual block (paragraph).

Task (no.2):

Working in threes, fill in the gaps in the text (3-4 mins) and pass it on to the next group. By ensuring the text follows on from the previous group's additions, attention is given to cohesion and coherence (light-hearted, serious, etc.). None of the groups should write on the same paper twice.

The aim of activities 1 and 2 is to combine verbal and non-verbal means of communication, encourage team working and to draw attention to the typicalword formulations used in such texts (fairytales). The activity given above supports creativity, deepens students' knowledge of realia and is a typical example of TPR (total physical response) method, when students are able to practise the vocabulary alongside with the physical activity (Buttner, 2007, p. 40).

Example no.2: Collective writing (level B1+, length of activity 25-30 $\underline{\text { minutes) }}$

Both of the preceding activities can be carried out (in seminars) with a text which is not so well-known (texts by contemporary Russian fiction writers are used with the aim of working with the "living" language, including slang) where students recieve an extract (ideally a dialogue) + key vocabulary which reflects the plot of a book.

Task for students:

Write a continuation to the given extract (without finding out the plot of the book). After finishing the activity (according to the time available, students working independently or in pairs for about 10-15 minutes) read aloud the individual completed extracts and respond to the extracts of the others (right at the end the teacher can reveal the real ending from the book). Give your opinion of the cultural-linguistic specifics of the text.

The aim is that, during writing all important categories are developed (emphasis on student-author development by means of suitably chosen language games, careful analysis of the text and language genre and with regard to the reader) so that the students can express the impact that the (Russian) writer's creation has on them as individuals from a different culture. It is obvious that making use of literary creations as an aesthetic phenomenon of national culture positively promotes the process of foreign language teaching and strengthens the intercultural perceptiveness (Prüvodce interkulturní komunikací, 2014, pp. 44-45).

Example no.3: Learning about an important personality - Bulat Okudzhava (level B1+, length of activity 20 minutes)

Task for students (homework):

At home watch the film about the poet B. Okudzhava (youtube.com/ watch?v=hUgl1c7k_zc). Find 5 key pieces of information about the poet and listen to two of his poems. Afterwards, write an essay (100-150 words) on the the theme "How to Retain Human Dignity in Every Situation". 
In the seminar students are given the lyrics of one of the best known songs from B. Okudzhava “Давайте восклицать" with some words missing.

Task for students (in seminars): Write (guess) the missing words even though you may not know the text - based on information about the author gained from homework. Then the teacher plays the song and students can compare their answers with the original lyrics. Which of the filled-in words (even if they aren't in the original) could stay without changing the meaning of the song? What is the main idea the songwriter is trying to convey?

The aim is to extend students' knowledge of realia, to experience the power of words, to work with them, learn how not to take things personally, not to react automatically but to strengthen creativity.

Example no.4: Proverbs in action (level B2, length of activity 25 minutes)

Task for students:

Working in groups of four. From a selection of 12 proverbs choose three from each category which for you characterize the mentality of eastern Slavs. In groups find reasons to support your arguments. Once you are agreed, in the time given, write a short article (essay, about 80-100 words) together using at least one of the proverbs and indicate which kind of periodical it might be published in (eg. a high-class magazine, a women's magazine or a magazine for teenagers, a tabloid newspaper, a children's magazine etc.).

The aim here is to extend students' knowledge of realia, solving communicative tasks, reinforcement and automation of phrases which are used in presenting arguments (the students have a list of such phrases available eg. projected onto the wall), training in switching between stylistic codes according to the target audience and work with colloquial language. Thanks to group work it's possible to build a group and to expand the students' active vocabulary through brainstorming. As a follow-up, for homework students could try creating a mini glossary (listing) not only on the conversational theme but also, for example, of academic vocabulary which is not tied to a specific branch of study.

Example no.5: He who laughs last.... (level B1, length of activity 25 minutes)

In the following exercise students work with Russian anecdotes - the aim is not to translate these into their native language, so avoiding the problem situation connected with so called verbal anecdotes. With this type of narration the emphasis is on the language devices i.e. the words which carry the punchline and which can't be replaced with a synonym without losing the comic effect, which makes this kind of joke pretty much untranslatable (in contrast to so called referential anecdotes, where emphasis is placed on the comic situation and individual words can be expressed with synonyms and easily retold).

Task for students:

Working in pairs of threes arrange the parts of individual jokes in order (four cut up anecdotes for pairs, six for groups of three) and identify the parts leading to the 
punchline and the punchline itself. Try to explain how the comic effect is achieved (situation as a whole, nature of the characters involved, language used-eg. lexicalsemantic, stylistic) determine the typical characters in Russian jokes compared to Czech ones. Try acting out the joke. Learn at least one joke by heart.

The aim is to strengthen socio-cultural competence, in this case a perspective on differing customs and patterns of behaviour of eastern Slavs, work with colloquial language (occasionally contact with dialect) and acquisition of new word connections emerging from the translated jokes which lends to the comic effect, such as an unexpected collocation.

For the purpose of using "living language" it is essential to always look for new material because even the best textbooks age with time. We therefore decided that in the seminars we would work with up-to-date videos with well-known presenters and commentators (eg. Vladimir Pozner, pozneronline.ru) or with the so-called "golden fund of Russian culture" (films, poems etc.).

Example no.6: Student press conference (level B2, length of activity - press conference 60-90 minutes)

Students have a video available for home preparation divided into individual blocks and they then divide up into individual roles (six experts according to the six blocks of video - politics, mentality, mass media, political parties, extremism, refugees) while the others play the role of journalists.

Task for students:

Watch the video clip at home (pozneronline.ru/2016/02/14150/) in which Vladimir Pozner responds to questions from journalists. Those students who play the experts prepare a glossary of terms from their field of expertise. Those playing the role of journalists must think of five questions from each field i.e. thirty questions in total.

In the seminar a practice students press conference is held where the journalists ask the six experts questions. Everything is recorded on video for feedback. The teacher and students can make a written evaluation of the video and give each other feedback.

The aim of this activity (role-playing games, which are not so widely used in the Czech education system) is to place emphasis on the autonomy of the students during their home preparation and furthermore to train them in giving prepared and spontaneous speeches as well as inactive use of current vocabulary (every term a different video is set with content and themes from current happenings in society).

Example no.7: Film art (level B2, length of activity 30-40 minutes)

Students work in the seminar with extracts from a popular Soviet film about the Great Patriotic War "Летят журавли“ which they have watched as homework. (Sosnowski, \& Tulska-Budziak, 2014, p. 114-118)

Task for students:

Having watched the film at home create (independently) a mind map on the theme of War and then in groups share your results. 
Theteacherplaysthe first extract (00:04.00-00.06.00) without sound. Work in groups of four, two students $(A+B)$ simulate the dubbing and after this the other two students $(C+D)$ give feedback. The students then switch roles and pair $C+D$ retell (this time without the film) what happened in the form of a conversation between, for instance, a neighbour and a shopkeeper and $A+B$ give feedback.

The teacher plays the second extract (00:26:45-00:32:22). Working in pairs, imagine that Boris has come to the flat to say goodbye but Veronica, for some reason, hasn't come. Write the farewell letter that Boris leaves for Veronica before he goes to war (50 words). Exchange the letters you have written and write Veronica's reply to Boris.

The teacher plays the third extract (1:02:30-1:06:00). In groups, respond orally to the question: What influence does the war have on the lives of the engaged couple? Is there a difference between the male and female view of the war. What is your view of war?

The aim of the activity is intensive work with listening exercises, activation of knowledge of historical wartime events and interpretation of an artistic work.

\section{Example no.8: Nonsense (level B1, length of activity 30 minutes)}

Task for students:

Choose a poem from an important Russian writer (eg. S. Pushkin, J. Lermontov, M. Tsvetaeva, C. Nabokov, B. Pasternak ...) and read it at home. Bring the poem to the seminar - read it out (taking care with the pronunciation) and the others must write down in their own words (i.e. in prose) the gist of the poem. Retell the poem from the point of view of one of the characters/things from the poem. Then work with key words from the poem and the associations they hold. Create your own sentences (they don't have to rhyme).

Students stand up and in order create sentences by adding one word at a time according to the model: adjective + subject + predicate + preposition + object + adjective + noun (eg. „Грустный журнал читает в библиотеке веселого мальчика“). The student who is unable to add a word sits down.

The aim of this activity is, above all, training in grammatically correct sentences on the basis of free association models (the sentences only need to make sense grammatically). Students practice reading (as part of their homework) as well as listening and speaking (during the seminar activity). During this type of activity students start to actively use previously gained vocabularly which they otherwise don't use so often (Sannikov, 2002, p. 63). As a functional (homework) task they could create a list of words (listing) according to individual categories (ideally, a category linked to the main idea of the individual poems which the students recited at the beginning of the activity).

For groups at B2 level classic language games can be used but made harder by insisting that every word in the sentence must start with the same letter (eg. „Василий вылил воду в ведро весенней Варвары“) (Buttner, 2007, p. 160). 


\section{CONCLUSION}

Survey among university students shows, that Russian language is chosen from several reasons (within the compulsorily optional subjects): regarding the application for future employment, because of traveling and educational stays at foreign universities. Another reason is the fact, that the Czech and Russian languages are Slavic languages and the classes are formed into smaller groups, comparing to English or German lessons. Approximately $90 \%$ of respondents were satisfied with offered creative activities (such are language warm-up exercises in the beginning of the seminar for increasing the mental condition or using the language games for revision and creating the casual atmosphere, etc.). Due to the creative approach to foreign language study, students evaluated the homework as more entertaining with better results also during the tests in the end of the terms.

Searching for creative methods and approaches helps to build language talent, and improvisation in language games and exercises prepares students to cope with real life situations and to develop independence. There is also strengthening of intercultural and communication competence, which are lately very emphasized ways of using the foreign language. In using any kind of language games and activation methods it is necessary to consider the needs of the students and their inner personality. On the basis of encouraging autonomous learning during activational exercises we want to emphasize that the teacher is not above the student but that they are both joining forces in seeking methods and strategies of how best to teach and learn a foreign language. It is shown that if there is a place where mistakes can be made without fear then something new and creative can arise. And for this reason we consider it important for students to provide mutual feedback and encourage each other in improving their language knowledge through teamwork.

We firmly believe that using creative methods and approaches in the teaching of foreign languages helps students in deciding to make foreign language learning a lifelong passion.

\section{REFERENCES}

[1] Alefirenko, N. F., \& Korina, N. B. (2011). Проблемы когнитивной лингвистики [Problems of cognitive linguistics]. Nitra: Univerzita Konštantína Filozofa v Nitre.

[2] Buttner, A. (2007). Activities, games, and assessment strategies for the foreign language classroom. Larchmont, New York: Eye On Education.

[3] Eibenová, K., Vavrečka, M., \& Eibenová, I. (2013). Hry ve výuce ruštiny: jazykové hry, hádanky k rozvoji řčci, dramatizace pohádek, tematické slovnícky: A1-B2 [Games for teaching Russian language: language games, riddles for speech development, dramatization of fairy tales, thematic lexicons: A1-B2]. Brno: Edika.

[4] Kotrba, T., \& Lacina, L. (2011). Aktivizační metody ve výnce: př́ručcka moderního pedagoga [Activation methods in teaching: handbook of contemporary educator]. Brno: Barrister\& Principal.

[5] Lojová, G., \& Vlčková, K. (2011). Styly a strategie ve výuce cizích jazyků [Styles and strategies in foreign language teaching]. Prague: Portál. 
[6] Maňák, J. (1998). Rozvoj aktivity, samostatnosti a tvořivosti žáků [Development of activity, independence and creativity of pupils]. Brno: Masarykova univerzita v Brně.

[7] Meier, D. (2000). The accelerated learning handbook: a creative guide to designing and delivering faster, more effective training programs. New York: McGraw-Hill.

[8] Prüvodce interkulturní komunikací [The guide to intercultural communication]. (2014). Prague: Dům zahraniční spolupráce.

[9] Sannikov, V. Z. (2002). Русский язык в зеркале языковой игры [Russian language mirroring language games]. Moscow: Языки славянской культуры.

[10] Serebrennikov, B., Kubriakova, E., \& Postovalova, V. (1988). Роль человеческого фактора $b$ языке: Язык и картина мира [Role of the human factor in language: Language and image of world]. Moscow: Наука.

[11] Сказки и рассказы для детей [Fairytales and stories for children]. (2010). Moscow: Православныймир.

[12] Sosnowski, W., \& Tulska-Budziak, M. (2014). С Россией на «ты»! Сиенарии уроков по русскому языку как иностранному [Being on first-name terms with Russia! Lesson examples for Russian as a foreign language]. Moscow: Русский язык. Курсы.

[13] Starko, A. J. (2014). Creativity in the classroom: schools of curious delight. New York: Routledge.

[14] Sternberg, R. J. (2012). The Assessment of Creativity: An Investment-Based Approach. Creativity research journal, 24(1), 3-12.

[15] Torrance, E. P. (1962). Guiding creative talent. Englewood Cliffs, NJ: Prentice-Hall. 